\title{
PREFACE: COLLECTING THE INTERVIEWS
}

Under the Black Umbrella chronicles the changes in Korea during the first half of the twentieth century, before and during the years when Korea existed as a colony of Japan. The Japanese presence hovered like a cosmic umbrella above the peninsula, casting a shadow of distrust, uncertainty, and fear over every life and every action. The takeover, to a greater or lesser degree, blocked the light of world awareness and left the Korean people living in the shadow cast by their colonial rulers.

My own knowledge of the Imperial Japanese colony originally came from two genres - the systematic detail in history books and the passionate stories of martyrs - and neither of these had prepared me for the gentle humor as my father-in-law recounted his early life. The family chuckled as father recalled entering a modern school dressed in old-fashioned banbok (traditional Korean clothing), and smiled as he remembered helping his family make noodles by standing on the handles of their old noodle press. I let his stories slip by one after the other, until suddenly it struck me that every story took place under Japan's onerous rule of the peninsula. Where were the atrocities I had come to expect?

His memories shook loose my narrow view of colonial life and made me aware that often, under that shade cast by the Japanese presence, some people, some of the time, led close to normal lives. Of course, I now realized, during those years there must have been the entire gamut of life experiences, but where were their voices?

I looked again at the available sources, and still found only the catalogue of events. It is inevitable that over time, powerful personal events gradually become impersonal facts and detach from the lives that generated them. However, these events did once live and breathe as real people, and it was those people I decided to find. I wanted to seek out the richness and complexities of life under Japanese rule by collecting oral histories from Koreans who had lived through those times. Their stories became this book, restoring life to this period of Korean history, and shattering the silence 
long held by many who lived under the black umbrella of Japanese colonial rule.

Together, my husband and I developed our plan. We set out to interview not only a distinct ethnic group but also a narrow age range within that group, so we took care to think through the interview process, considering both what the older Koreans would deem respectful and what would put them most at ease. We knew that many, if not most, of these elders live within the cultural protection of the Korean community, rarely deal with Caucasians, and speak limited or no English. First we ruled out my typical western forthrightness, and planned that my husband, a native Korean speaker, would conduct the interviews.

He began by interviewing the most elderly Koreans in our San Francisco Bay area-first friends, then acquaintances, then those attending Korean senior centers. One by one, he traveled to each of the centers of the San Francisco Bay area and met with the presidents of the associations. After sharing tea and general conversation, he explained our project, presented his business card, and made clear his University of California affiliation. He left with an appointment to interview the president, and spent the next hour circulating and meeting individual elders. Then he returned week after week, tape recording interviews.

He began gently. Perhaps people would not want to bring forth old, possibly traumatic, memories - and at first people did hold back. "Oh," they said, "nothing much happened to me." Gradually, however, as they became used to this visitor and his tape recorder, individuals approached him saying, "You haven't heard my story yet," or "I have an interesting story to tell." Again and again he heard the comment, "I haven't talked about this in years," or "No one ever asked me that before." But memories returned quickly, and simple questions often released powerful stories.

In all interviews except one, the elders preferred to speak in their native Korean, and thus we had a second job at home. My husband translated the tapes into English, doing his best to catch the subtleties of Korean language with its different levels of speech. I typed the stories into the computer and puzzled over ways to organize and synthesize the thousand pages of material-what to include and what to leave out.

Inclusion began with one overarching goal-to document diversity. Stories were then excluded that fell into one of two categories-uneventful 
or redundant. Some people said that nothing much happened to them, and they were correct. Yet in their quiet lives there were often small moments of interest, and these entered the collection of smaller vignettes.

Next we sought to exclude redundancy. Many people shared similar experiences, especially at school or at work. From these, we chose the stories where details or personalities came through most strongly.

One single collection of stories cannot hope to capture the complete picture of life across an entire country, and our selection is admittedly limited by the locale from which we gathered our respondents-they are all people who wanted and could afford to move to America. The stories might take on a different tone if, for example, they had been gathered from among Koreans who had stayed in Korea, in North Korea, in Yanbyan, Manchuria, or from among those forced to labor in and still residing in Osaka, Japan.

In spite of this limitation, the stories presented here show lives that range from poverty to riches, and from comfort and acceptance to fear and torture. We are constantly reminded that even under the black cloud of Japanese rule, life was never one-dimensional.

The interviews in this book are arranged into six major stories and many small vignettes. We chose these six longer stories for the diversity of their experiences, and made no effort to reflect the percentage of poor, average, or well-to-do families. Yet looking at them now, we realize that of the six, two (Hong Ŭlsu and Chǒng Chaesu) started in severe poverty-one staying and the other rising by his own efforts; two (Kang Pyŏngu and Yu Hyegyŏng) came from prominent families and in spite of troubles, stayed there; and two (Yi Hajŏn and Yi Okhyŏn) were born into prominent families and pulled down by their troubles.

In all cases, to help jog their memories, we presented the elders with open-ended questions covering their town, schooling, jobs, religion, contact with Japanese authorities, and name change from Korean to Japanese. In addition, we encouraged them to relate any other experiences they remembered as significant in their lives. Taken together, the fifty men and women interviewed represented a wide range of occupations, education, birth locales, and religious beliefs.

This collection has three caveats. First, I acknowledge that these stories do not necessarily represent all Koreans; second, I acknowledge that not all 
memories may be completely accurate; and third, in a matter of semantics, I have not always translated the word communist as given us by the Korean elders.

First, with the exception of my father-in-law's memories taped years ago in Seoul, the interviews are from people living within a reasonable commute between Monterey and San Francisco, California. This may raise questions about the types of people most likely to emigrate, and whether their stories are skewed as a result. We found, however, that our local area was not restrictive, for over 100,00o Koreans now live in the greater San Francisco Bay area. The elders interviewed were both independent and dependent, educated and illiterate. They had been farmers, businesspeople, teachers, and scientists.

Second, memories are just that-memories. Each one is full of the passion of personal involvement. Many are clear and accurate, while others are colored by emotion or rumor. Throughout the book, small building blocks of historical information are supplied in an attempt to set these memories in context.

Beyond the scope of this book, but perhaps food for further discussion, are questions considering the veracity of remembered content, the effects of time and distance on memory, and the selectivity of geriatric reminiscences. Researchers with knowledge of colonization history may choose to consider whether or not the Korean situations are unique when compared with other colonized countries around the world.

Finally, in translating these memories, I have attempted to reserve the label communist for Communist Party members or their activities and to use the terms leftist, radical, or partisan in areas where actual membership in the party may not have existed. During the colonial years, various groups-leaning right, middle, and far left-worked to free Korea from Japan, and in that sense, all were nationalists. During the 1920 s various communist groups entered Korea, all with the common goal of resistance to Japan. The current antagonism between Korean communists and nationalists emerged at the I945 division of the peninsula into two countries, and from then on, the political groups polarized into "bad guys" and "good guys" (or reversed, from the northern point of view!).

In spite of these caveats and questions left unanswered, this book presents a fresh view of Korean history, told by the people whose lives, with both conscious effort and unconscious acceptance, intertwined the dis- 
parate themes of political oppression, economic gain, and personal passage from the ancient to the modern world. These elders graciously shared their memories with us and have given us a clear and varied picture of life under the black umbrella of the Japanese occupation. We offer them our thanks.

H. K.

Livermore, California 
